\title{
BER-ENGLISH RIA ENGLISH SPEAKING COMMUNITY: POLITENESS USED
}

\author{
${ }^{1}$ Annisa Nurul Shabrina, ${ }^{2}$ Sukma Nur Ardini \\ ${ }^{1}$ Universitas Negeri Semarang, Semarang \\ ${ }^{2}$ Universitas PGRI Semarang, Semarang \\ (annisanurul365@gmail.com) \\ 2 (sukmanurardini@upgris.ac.id)
}

Article History: Submitted May $1^{\text {st }}, 2019$; Accepted June $2^{\text {nd }}, 2019$; Published July $5^{\text {th }}, 2019$

\begin{abstract}
As the fast development of technology in this globalization era, people become more attracted to social media. In using social media itself, we still need politeness just like the face-to-face communication. This study wasaimed at analyzing the politeness strategies used in Ber-english Ria'Line' group chat. The study described the politeness strategies used in Ber-english Rialine group chat and the application among those strategies. The study was analyzed descriptively based on related politeness strategies classification of Brown and Levinson(1987). The data were analyzed and grouped into the classification. The result showed that the group chat members mostly used positive politeness followed by negative politeness, off record strategy, and the least used is bald on record strategy. It showed that the group chat members' politeness was in the middle of very polite and straightforward.In the end, the most applicable politeness strategy used in Ber-english Ria 'Line' group chat was positive politeness strategy. The result of this study showed how important the politeness even in written communication. It can be used in using social media to lessen the misunderstanding.
\end{abstract}

Keywords: politeness; English speaking community; group chat

\begin{abstract}
Abstrak. Seiring dengan cepatnya perkembangan teknologi di era globalisasi, orang-orang menjadi bergantung dengan media sosial. Di dalam menggunakan media sosial sendiri, kita masih membutuhkan kesopanan seperti dalam komunikasi tatap muka.. Penelitian ini bertujuan untuk menganalisis jenis dan penggunaan politeness strategies yang digunakan dalam grup percakapan 'Line' Ber-english Ria.. Percakapan tersebut dianalisis secara deskriptif berdasarkan klasifikasi politeness strategies milik Brown dan Levinson (1987). Data dianalisis dan dikelompokkan menurut klasifikasi tersebut. Hasil menunjukkan bahwa anggota grup percakapan kebanyakan menggunakan positive politeness diikuti dengan negative politeness, off record strategy dan terakhir bald on record strategy. Hal ini menunjukkan bahwa kesopanan anggota grup percakapan ada di tengah sangat sopan dan terang-terangan. Pada akhirnya, politeness strategy yang paling banyak digunakan dalam grup percakan 'Line' Ber-english Ria adalah positive politeness strategy. Hasil penelitian ini juga menunjukkan bagaimana pentingnya kesopanan bahkan dalam komunikasi tertulis. Hal tersebut dapat digunakan dalam penggunaan media sosial untuk mengurangi kesalah pahaman.
\end{abstract}

Kata kunci: kesopanan; komunitas penutur bahasa Inggris; grup percakapan 


\section{INTRODUCTION}

In this globalization era, people are able to communicate through their smartphones. Social media and messaging applications are made and can be accessed easily on their smartphones. That is why people can easily text each other using social media or messaging application. The interesting features in social media or messaging application make people use them over and over again every day.

There are two kinds of communication; face-to-face and written. Face-to-face communication is more like spoken language. It is directly from the conversation between people. Meanwhile, written communication is likely written language. It needs written words to deliver the purpose of people who communicate. As technological development, many people use written text in daily life for informal needs. They use written communication in delivering a lot of information through messaging applications, and not all of them use formal language on messaging application.

Besides two kinds of communication above, language plays an important role in communication. People cannot communicate well without language as Sirbu (2015) stated that language is essentially a means of communication among the members of a society. It means language is the main means in society to communicate with others.

The problem begins to come up in using language for communication, especially in written communication. Unlike face-to-face communication where we can know the intonation of the speaker and even the expression, we only could be able to read the words from written communication. However, there is politeness in language use. We can avoid misunderstanding by using proper politeness in written communication, especially through the messaging application. What is meant about politeness, according to Cook (2001) politeness is a set of a maxim that expects to appear when people performing the utterance. It also expects to appear in communication through messaging application. On the other hands, Holmes (2015) states that politeness is related to the respect of the interaction between mutual. In other words, Jumanto (2014) states that politeness is everything good that has been uttered as well as acted by the sepaker to the hearer within a particular context, to maintain their interpersonal face as well as their social face. Hence, politeness can build respect interaction between mutual. It is not only face to face interaction but also in social media or messaging application.

By the reasons above, the study aimed at analyzinghow people are using the politeness strategies when they do written communication through messaging application. It is therefore important to look at the definition of English speaking community, politeness theory, and the definition of 'Line'.

\section{English Speaking Community}

In this study, the English speaking community is defined in another way anglo (anglophone). Anglo is an ethnic term of relativity recent vintage used to distinguish those English ethnics or English-speaking background from the others. (Merriam-Webster, 1989). The English speaker here does not have to consider English as their first language or mother language. Otherwise, they use English as a second language. The researchers used this term to define Indonesian people who use English as their second language. 


\section{Politeness}

Politeness is one of the important thing in communication. It can maintain a good relationship and continuance in the process of communication. The communication will be well done with a proper politeness. Both in verbal and non-verbal communication, the use of politeness is needed to achieve the said purpose earlier. Especially in social media where people usually only communicate with verbal language such as texting. People do not really show the non-verbal language there. The politeness will be discussed more below.

According to Cook (2001), the politeness principle is a set of a maxim that expects to appear when people performing the utterance. In a communication with each other, people often use it to give the respect. Holmes (2015) stated that politeness is related to the respect of the interaction between mutual. Holmes (2013) also argued that in daily life, politeness is a formal behavior that expresses respect for other. So politeness is simply something you can find in everyday life related to the respect behavior to other.

In the politeness, there is a term called 'face'. According to Goffman (1955) face is the positive public image to establish in social interaction. Domenici and Littlejohn (2006) stated that the term 'face' is a metaphor for literally face for the identity of ourselves that we show to other. However, Holmes (2013) stated that everyone has 'face' that needs to be maintained, either their own face or the hearer's face. Although the term of the face has been explained in a various way, we can conclude that 'face' is an image that people look for build the social image so they can be approved and respected.

The 'face' is listed into two aspects; negative and positive face. The negative face is a personal orientation to express the freedom and the action of their self. It is the need to have freedom of action, and not to be imposed by others. Meanwhile positive face is an image that they build so other people appreciate them. It is the need for self-image to be accepted, appreciated, and approved of by others. To be treated as the member of the same group and to know that his wants are shared by others.

In order that everyone has 'face', they also want to keep or save it to keep a good image in society. Face saving acts are oriented toward both negative and positive face. Face saving toward negative face will tend to show deference, emphasize the importance of the other's time or concern, and even include an apology for the imposition or interruption. Then face saving act towards positive face will show solidarity, emphasize that both speakers want the same thing, and they have a common goal.

Furthermore, there is a term called Face Threatening Act (FTA). It is an act that inherently damages the face of the hearer or the speaker by acting in opposition to the wants and desire of the other. And from the FTA, it will be ended on facework. Brown and Levinson used Goffman's face theory as a foundation for explaining human interaction that revolved around being polite. In developing politeness theory, they expanded and added to face theory by arguing that we have two faces; positive and negative face. The diagram below shows the plot of face. 


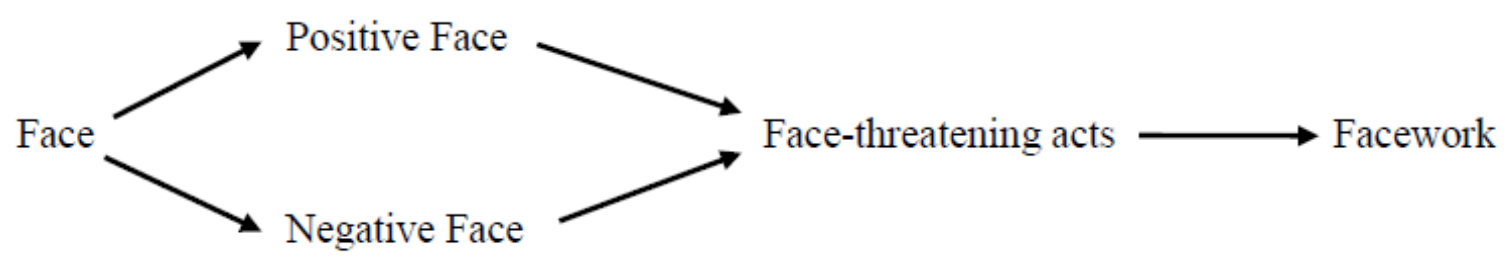

Figure 1 Face on politeness

As the correlation of FTA in politeness, it contributes to the main purpose of politeness. The main purpose of politeness itself is to avoid FTA that lead to humiliate both speaker and hearer. By that main purpose of politeness, there are some categories of politeness strategies to avoid or lessen the possibility of a humiliating speaker and hearer's face. Brown and Levinson (1987) divided the politeness strategies into 4 categories, it follows:

\section{Off Record}

It is the speaker indirectly asks something by telling his situation in a hope the hearer would understand. This strategy is the most polite and indirect. It makes ambiguity. It includes give hints, use metaphor, be vague, and be sarcastic.

\section{Negative Politeness}

It is focused on the addresser's negative face. It presumes that the speaker will be imposing the hearer is a higher potential for awareness or embarrassment. The speaker desire to be autonomous (self-governing), free, not imposed on by others, and respected by others in terms of time, privacy and possession. It includes be indirect, be pessimistic, request of forgiveness, minimize imposition, pluralized the personal responsibility. In using this strategy, people desire to be autonomous, free, not impose by others, treated as a group member, being respected in society.

\section{Positive Politeness}

It is usually use in the same ground of both speakers'. This strategy makes the hearer feel good about themselves, interests, or possessions. It usually uses when there is less social distance between speaker and the hearer; they are close to each other. It includes attend to the hearer, avoid disagreement, assume agreement, seek agreement, offer promise, be optimistic and hedge opinion,

\section{Bald on Record Strategy}

It is the most direct and unambiguous strategy. The speaker would directly ask what they want. It includes an emergency, task oriented, request, and alerting.

These strategies are listed from the most polite one to the most direct one and the chosen of remaining silent. In the other way, the politeness strategies can be explained in a scheme below. 


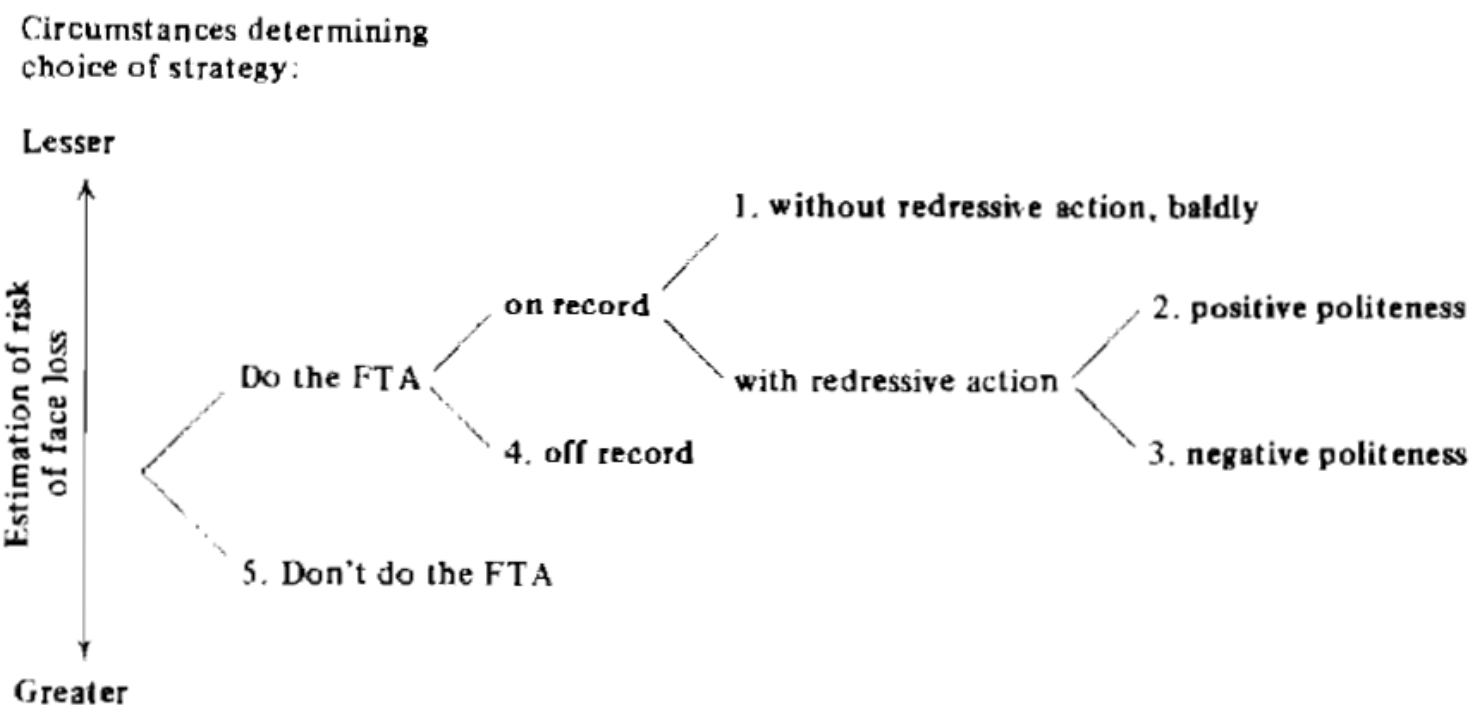

Figure 2 Politeness strategies (Brown and Levinson, 1987)

Just like the explanation before, this scheme also shows the politeness strategies from lesser to the greater estimation of risk of face loss (humiliation face). In this case 'Do the FTA' groups shows the effort to lessen the risk of face lose. Meanwhile, "Don't do the FTA" in the scheme shows nothing to lessen the risk of face lose. People usually just keep silent or do not respond in this case. They tend to avoid it.

The use of those strategies itself is based on the condition and context. It is also based on the relationship between speaker and hearer. The power between speaker and hearer really affects the usage of politeness strategy. People with less power usually use the most polite strategy to people with more power than them. It also shows the good attitude for them.

\section{Line}

Line is a free messaging application with a lot of features such as group chat, voice and face call, etc. It is available for a variety of smartphone devices (iPhone, Android, Windows Phone, BlackBerry, and Nokia) and even personal computer. (https://line.me/en/) Line, with all the features, lets you keep in touch with your beloved no matter how far they are.

\section{METHOD}

\section{Design of the Study}

In this study, the researchers used a qualitative method. Based on Miles and Humberman (1994), qualitative research is arranged in a firm relationship to the real situation. Furthermore, Miles and Humberman (1994) stated that the data of qualitative is likely in words form and not numeral. The goal of qualitative approach and supported by 
quantitative research is "a holistic and depth of understanding rather than a numeric analysis of data" (Ary et al, 2010). Qualitative is chosen since the researchers will not focus on the numeral but the utterances of the conversation. Moreover,the researchers used descriptive research. It aims to describe the result of analyzing data on this research. Since the study is qualitative descriptive, the researchers described the result of the analyzed utterance in group chat conversation as the data.

\section{Object of the Study}

The object of this study is Line group chat so called Ber-englishRia. It is a line group chat where the members learn to improve their English ability by using English in their conversations. Any topics can take to this group as the main focus of this group is improving the members' English skill. The researchers chose this group because the members use English in the conversation. The researchers used the utterance of the conversation and analyzed its politeness strategies. The researchers took the utterance of this Line group chat start from January $17^{\text {th }}, 2018$.

\section{Instrument of the Study}

In this study, the researchers used to take note as the instrument. The researchers analyzed the conversations of the 'Line' group chat to find out the politeness strategies used by the members of 'Line' group chat.

\section{Method of Data Collection}

The writer had to collect the data in this study. The data itself was used for the research purpose. The researchers used some methods to collect the data in this study. The methods are document research, library research, and internet research.

\section{Method of Data Analysis}

This study used qualitative research which was more focused on the politeness in utterance of Line group chat than the numeral data. The writer got the data from the conversations in the Line group chat. After that, the writer had to analyze politeness of the member's group chat. The analysis was purposed to discover what politeness are used in the conversation. The writer did this procedure to analyze it, there are reading, listing, analyzing, and concluding.

\section{RESULTS AND DISCUSSION}

The group chat was started from January 17th, 2018. There were a lot of conversation happened with a lot of different topics, but the researchers has chosen 185 utterances that used politeness strategies. As stated on the previous chapter, all sentences in the group chat were grouped into four politeness strategies by Brown and Levinson (1987); off record, negative politeness, positive politeness, and bald on record strategy. The result of the grouping is described below. 


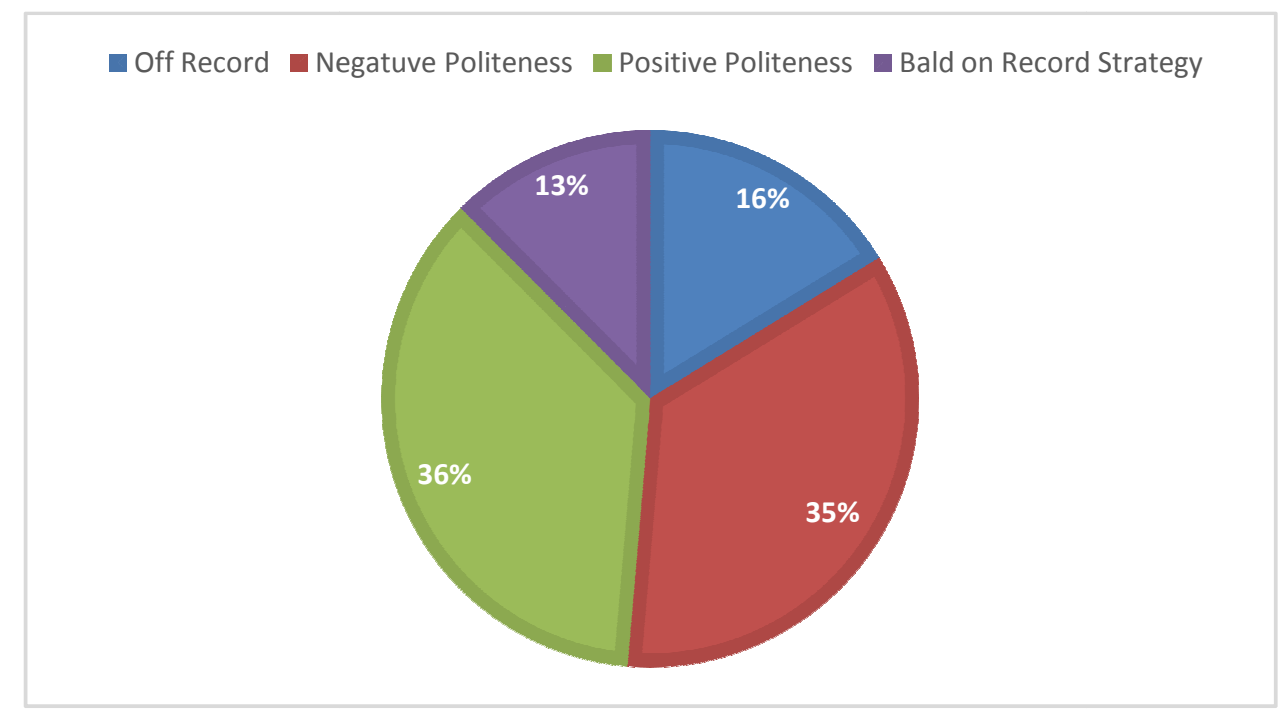

Figure 3 Total of Politeness Strategies Used on 'Line' Group Chat

The table shows that the group chat members mostly used positive politeness with percentage $36.2 \%$ followed by negative politeness with percentage $35.1 \%$. After that it is off record strategy with percentage $16.2 \%$ and the least used is bald on record strategy with 12.5\%. As Holmes (2015) stated that politeness is related to the respect of the interaction between mutual. The group members also used politeness strategies to give respect to the other group members. The usage itself was different in every way. The usage of politeness in the group chat was based on the condition and the context. It would be different on every topic. The differences in a relationship between the group members are also affected by the usage of politeness strategies. The explanation below shows the application or usage of politeness strategies on group chat.

First is off record strategy. In this strategy, the speaker indirectly asks something by telling his situation in a hope the hearer would understand. This strategy is the most polite and indirect. It causes ambiguity. Some responded members of the group chat used this strategy when they responded or stated something in the conversation. They used the strategy with a various expression such as:

"It should be a long story."

"What a sad morning story."

"Hello guys! I hope all of you are not a grammar nazi."

"You got a cute gif there, Yura. Lol."

"Seems like i'm the oldest here."

Above were only a few responses and statements of group chat members that used off record strategy. The member indirectly asks something by telling their situation in hope that other members would understand just like the sentence "Hello guys! I hope all of you are not a grammar nazi." It showed that the particular member hoped the other members would not correct the grammar as the conversation happened. Meanwhile, the researchers found sarcasm was used in the sentence "You got a cute gif there, Yura. Lol.". Since off 
record are the most polite strategy from all of the strategies, some members used it in hope they would not threatened the face of other members.

The second strategy is negative politeness. This strategy is focused on the addresser's negative face. It presumes that the speaker will be imposing the hearer is a higher potential for awkwardness or embarrassment. The speaker desire to be autonomous (self-governing), free, not imposed but also respected by others in terms of time, privacy and possession.

Considering the negative politeness, the researchers found quite a lot sentence that used this strategy. This strategy was eventually the second most used strategy in the group chat. The members of group chat used the strategy with various expressions such as:

"Hi btw im not really good at english so you better understand haha.

"Should I change my dn?"

"My lecturer is comiiiiiing"

"Sorry we're busy tell story each other"

"Maybe everyone's at school or they have a class?"

The group chat member used it as wanted to maintain the distance from other members so instead of stating the direct intention, they expressed it as "Should I change my dn?". Also the apology in "Sorry we're busy tell story each other" was used in order to sound as polite as possible.

The third strategy is positive politeness. This strategy is usually used in the same ground for both speakers'. This strategy makes the hearer feel good about themselves, interests, or possessions. It usually uses when there is a less social distance between the speaker and the hearer; they are close to each other. Considering the positive politeness, the researchers found a lot of sentences used this strategy in the conversation such as:

“That's not really matter as long as my friend doesn't know abt it"

"Inaguration of what?"

"You will improve soon. Practice makes perfect"

"But we're usually dont speak much hahaha"

"Can I laugh first?"

In order to use this strategy, the member showed the optimistic. The member wanted to raise the confident of the other members they said "You will improve soon. Practice makes perfect" or the direct saying of the expression as "But we're usually dont speak much hahaha"

As the researchers stated before, this strategy makes the hearer feel good about themselves, interests, or possessions that is why most of the group chat members used it. The atmosphere of the group chat would be nice when the members used this strategy. All of 
them felt like they are close and just talked casually even still with the politeness strategy on it.

This strategy used when there is the less social distance between the speaker and the hearer or it can say that they are close to each other. As the time passed by and the other members felt close to each other, they tended to use this strategy to sound more casual.

The last strategy is bald on record. This strategy is the most direct and unambiguous strategy. The speaker would directly ask what they want. It sounds very impolite but there are contexts in which it is the only appropriate strategy such as a very close friend. Based on the conversation in group chat, there were only a few sentences used this strategy:

"Call me puji or whatever do you want"

"So happy to know that there is no grammar nazi here"

"For me, the real stupid people are racist people"

"Wait a second still typing"

"Cmon, I wanna hear the story"

All the sentences above shows the direct and explicit intention of the speaker. They used the imperative syntatic structure (direct directive) such as 'call me' in "Call me puji or whatever do you want". Some members used it in certain situation to make it more straightforward and in some case they used it to their close member.

From the most to least politeness strategy that group members used, we can see that they want to still manage the politeness. Even some of them are not close to each other. But even they are not close to each other, they are still comfortable talking to each other with the politeness strategies' used. It is a good thing so they make a good relationship. Moreover, it can lessen the misunderstanding between the group members.

\section{CONCLUSION}

The politeness strategies analysis of Ber-english Riagroup chat showed some conclusions. First, the most used strategy was positive politeness and the least one was bald on record strategy. It showed that the group chat members' politeness was in the middle of very polite and straightforward.Some members considered the other member which are not close friends. They wanted to keep the good image (positive face) of themselves and also the good relationship between each other. That was the reason why they mostly used positive politeness. As time went by, some members felt they got closer with other members so the straightforward politeness strategy such as bald on record strategy was started to come out. It can be concluded that the members wanted to be seen casual when they got closer.Second, this study can be a factual example of how people interact in social media. Even in written communication, the politeness is still needed. The politeness in written communication can manage a good relationship and lessen the misunderstanding. 


\section{REFERENCES}

Ary, D., Jacobs, L. C., an Sorensen, C.K. (2010). Introduction to Research in Education ( $8^{\text {th }}$ ed). Belmot, CA: Wadsworth/Thomson Learning.

Brown and Levinson. (1978). Politeness: Some Universals of Language Use. Cambridge: Cambridge University Press.

Cook, Guy. (2001). Discourse. Oxford: Oxford University Press.

Domenici and Littlejogn. (2006). Facework. California: SAGE Publisher.

Goffman, Erving. (1955). On Face-work: An Analysis of Ritual Elements in Social Interaction. Psychiatry: Journal for the Study of Interpersonal Processes, 18, 213231. doi: https://doi.org/10.1080/00332747.1955.11023008

Holmes, J and Stubbe, M. (2015). Power and Politeness in Work Place.London: Routledge

Holmes, J. (2013). Women, Men, and Politeness. New York: Routledge.

Jumanto. (2014). Politeness and Camaraderie : Type of Form Matter in Indonesian Context. International Conference on Education and Language (ICEL) Bandar Lampung University, 2, 335-350. Retrieved from http://eprints.dinus.ac.id/15167/1/Jumanto-305-556-1-PB.pdf

Merriam-Webster. (1989). Webster's Dictionary of English Usage. Springfield : MerriamWebster Inc Publisher.

Miles, M. B. And Huberman, A.M. (1994). Qualitative Data Analysis. California: SAGE Publications.

Sirbu, A. (2015). The Significance of Language as A Tool of Communication. PROQUEST ScoTech Journals. 


\section{APPENDIX}

The Application of Politeness Strategies by Members of Ber-englishRia Group Chat

\begin{tabular}{|c|c|c|}
\hline NO & $\begin{array}{l}\text { POLITENESS } \\
\text { STRATEGY }\end{array}$ & THE APPLICATION \\
\hline \multirow{20}{*}{1} & \multirow{20}{*}{ Off Record } & It should be a long story \\
\hline & & What a sad morning story \\
\hline & & What do you think? Its my fault or nah? \\
\hline & & But $u$ can pass urhighschool rite? \\
\hline & & $\begin{array}{l}\text { No my friend going to bullying me (as joke) and my } \\
\text { smell caught by them }\end{array}$ \\
\hline & & Really? Your friend dont knew about that? \\
\hline & & There are no one will say welcome to me? \\
\hline & & What a englishplsi'm so bad at english \\
\hline & & Even if google translate make some fault too \\
\hline & & $\begin{array}{l}\text { Lets just pretend that you're good enough so you don't } \\
\text { have to be shy }\end{array}$ \\
\hline & & $\begin{array}{l}\text { I already studied about grammar since i was } 13 \text { but my } \\
\text { grammar still suck }\end{array}$ \\
\hline & & $\begin{array}{l}\text { I've seen some wrong grammar but idont care since i'm } \\
\text { suck at grammar too }\end{array}$ \\
\hline & & You got a cute gif there, Yura. Lol \\
\hline & & Seems like i'm the oldest here \\
\hline & & Like eumnata de coco? \\
\hline & & $\begin{array}{l}\text { But most people said i'm stupid when they're disagree } \\
\text { with my opinion because i'mchinese }\end{array}$ \\
\hline & & $\begin{array}{l}\text { They should relearn about Pancasila and something related } \\
\text { PPKN }\end{array}$ \\
\hline & & $\begin{array}{l}\text { I think you have to tell us about your other story. It can } \\
\text { make a long conversation }\end{array}$ \\
\hline & & Damn why is life so hard \\
\hline & & Tomorrow is the first day of my collage, so wml \\
\hline
\end{tabular}




\begin{tabular}{|c|c|c|}
\hline & & There's a lot samyang left at my house \\
\hline & & Anyway jokowi is here \\
\hline & & Im actually nervous right now \\
\hline & & Waiting for an announcement soowih me luck \\
\hline & & OMG I MISS YOU GUYS \\
\hline & & $\begin{array}{l}\text { So i decided to write my story in wattpad. If you guys } \\
\text { interested in reading it. here's the link to my story. }\end{array}$ \\
\hline & & I'm sleepy \\
\hline \multirow{18}{*}{2} & \multirow{18}{*}{ Negative Politeness } & $\begin{array}{c}\text { Hi btw im not really good at english so you better } \\
\text { understand haha }\end{array}$ \\
\hline & & Should I change my dn? \\
\hline & & Eh, a twin? \\
\hline & & No of course, it will be nice to have two dina(s) here \\
\hline & & So, who still student just two people here? \\
\hline & & Where do you guys come from? \\
\hline & & My lecturer is comiiiiiing \\
\hline & & $\begin{array}{l}\text { Sorry for the late greetings. My phone getting full of } \\
\text { storage so.. it takes time to load this line }\end{array}$ \\
\hline & & Would u tell us what's your problem? \\
\hline & & What grade are you in? \\
\hline & & Sorry we're busy tell story each other \\
\hline & & You can join us \\
\hline & & Hey nata so now you have collage? \\
\hline & & $\begin{array}{l}\text { Hahah but you both dont feel stifingly hot? Then } \\
\text { sweating? }\end{array}$ \\
\hline & & Where do you go to college nat? \\
\hline & & I cant speak banjar, my bad \\
\hline & & Sorry for my absurd typing. That was typo \\
\hline & & Sorry for speaking banjar \\
\hline
\end{tabular}




\begin{tabular}{|c|c|c|}
\hline & & $\begin{array}{l}\text { Honestly i feel so embrassed when i talk in english 'cause } \\
\text { my english is sooooo bad. Thank to owner who make this } \\
\text { group }\end{array}$ \\
\hline & & Woaah maybe someday we can meetupeum? \\
\hline & & $\begin{array}{l}\text { Yeah but too much grammar nazi now who make someone } \\
\text { who want to learn english feel so sad and then they will be } \\
\text { stop learn }\end{array}$ \\
\hline & & $\begin{array}{l}\text { Yes ikno that feels. It makes us feel so shy to speak } \\
\text { English }\end{array}$ \\
\hline & & $\begin{array}{l}\text { Eumm can i get some corrected when i want to be correct } \\
\text { in here? I want to be better in english }\end{array}$ \\
\hline & & Ahh sorry kkk \\
\hline & & $\begin{array}{l}\text { Sorry oot. Why when I try to explain my opinion and } \\
\text { people doesnt understand about my opinion also disagree } \\
\text { they said I like a dumbass or otakudang or curshing word } \\
\text { else }\end{array}$ \\
\hline & & What related with chinese? Diskriminatif \\
\hline & & Maybe you can pinned it? \\
\hline & & Why it is already sepi \\
\hline & & Maybe everyone's at school or they have a class? \\
\hline & & Why grup being sepi \\
\hline & & Story about what ya? \\
\hline & & Anyone want to tell me some curhatan? I'd like to hear \\
\hline & & I need to your opinion on something \\
\hline & & $\begin{array}{l}\text { I want people to read it. the thing is idont really like to } \\
\text { write in bahasa? I want to write in english but idont know } \\
\text { where }\end{array}$ \\
\hline & & $\begin{array}{l}\text { Do you guys think i should in wattpad? Or do you have } \\
\text { some recommendation? }\end{array}$ \\
\hline & & Mind to try to post it on aff? \\
\hline & & I guess you called dita \\
\hline 3 & Positive Politeness & $\begin{array}{l}\text { College was fun until the homework strikes in and the } \\
\text { quiz and the stress }\end{array}$ \\
\hline
\end{tabular}




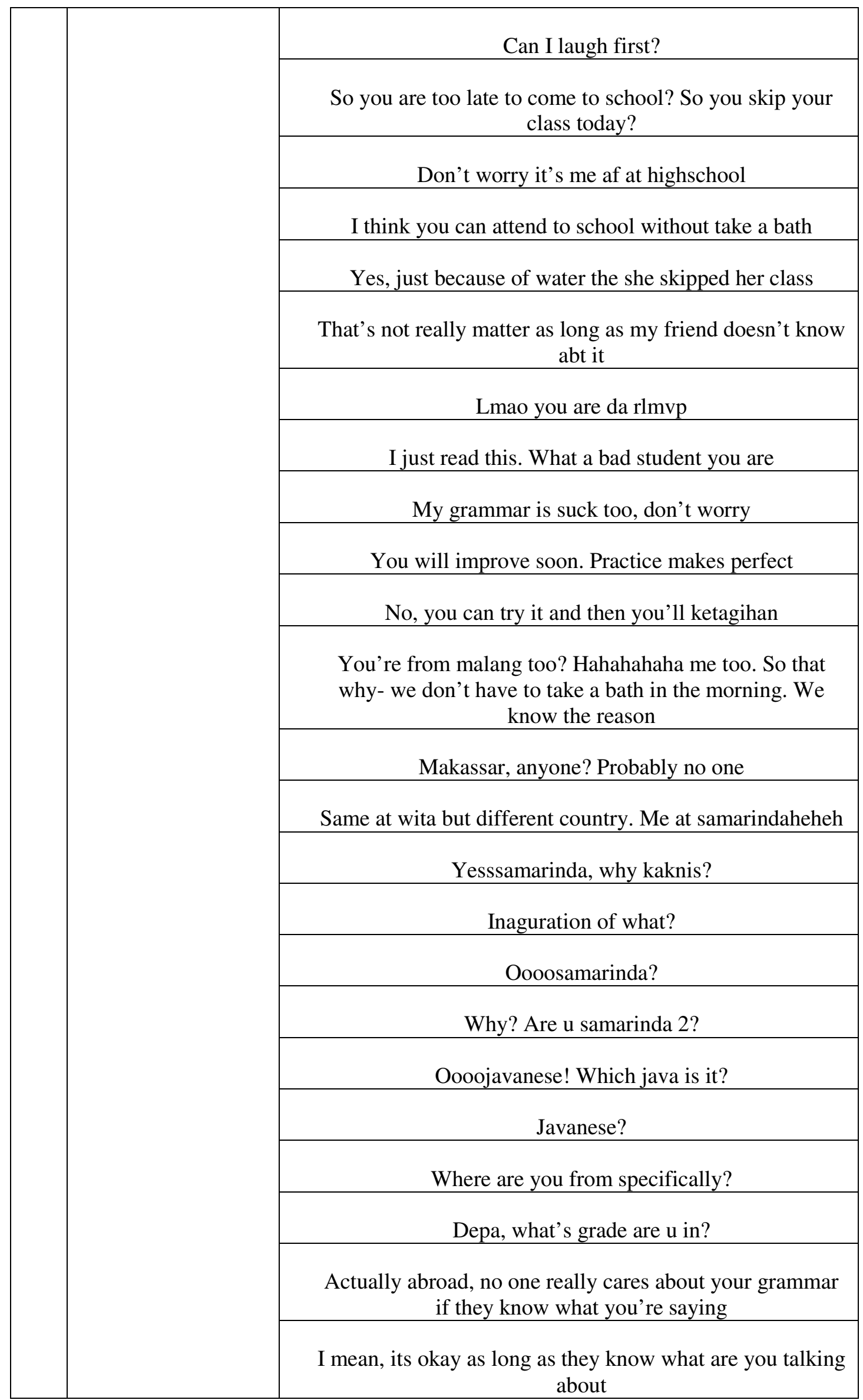




\begin{tabular}{|c|c|c|}
\hline & & $\begin{array}{c}\text { Google translate only translate in words not sentence i } \\
\text { guess? Thats why it got so bad }\end{array}$ \\
\hline & & $\begin{array}{l}\text { Hahahahathats why i never use google translate when i } \\
\text { talk or have some sentence in english }\end{array}$ \\
\hline & & Its okay. They will teach $\mathrm{u}$ from the most basic things \\
\hline & & I can help you if you want \\
\hline & & $\begin{array}{l}\text { But dont worry just like annisa said, they will teach you } \\
\text { from the basic }\end{array}$ \\
\hline & & $\begin{array}{l}\text { English is a language. As long as ppl understand what u } \\
\text { say, there's no need to feel shy }\end{array}$ \\
\hline & & Are you meh lisa!?!? \\
\hline & & What song? \\
\hline & & Isnt it twice? \\
\hline & & Woah we're on the same ship! \\
\hline & & Anybody same like me here? \\
\hline & & $\begin{array}{l}\text { Whatever you're chinesekahjavanesekah you're just } \\
\text { human }\end{array}$ \\
\hline & & $\begin{array}{l}\text { Anwi have to put a reminder that i curse a lot, please mind } \\
\text { me. But if there's any of you uncomfortable with it just } \\
\text { tell me ok i will try to hold it }\end{array}$ \\
\hline & & Dont forget to check note yap \\
\hline & & But we're usually dont speak much hahaha \\
\hline & & $\begin{array}{l}\text { Also this group was made for us to improve our english so } \\
\text { please bare with it if you find our topics are random }\end{array}$ \\
\hline & & How's your sleep guys? \\
\hline & & Are u guys still alive? \\
\hline & & Lets talk about smth \\
\hline & & But wattpad sounds great too for me \\
\hline & & Call me puji or whatever do you want \\
\hline 4 & Bald on Record & Wait a second still typing \\
\hline & & Yup. But, just sepele problem \\
\hline
\end{tabular}




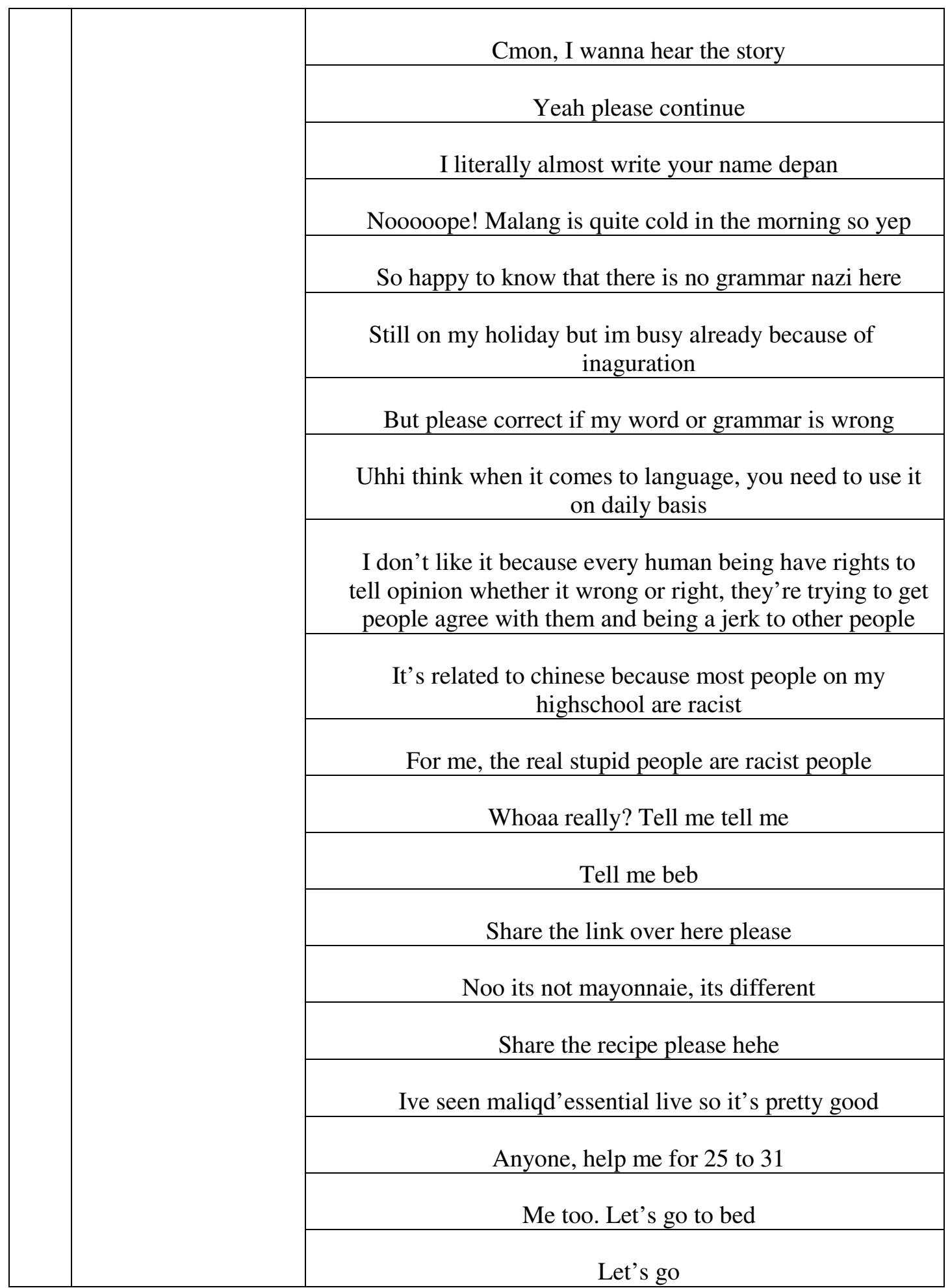

